\title{
PENGARUH PENERAPAN SISTEM AKUNTANSI TERHADAP KUALITAS LAPORAN KEUANGAN
}

\author{
(Studi kasus pada CV. Mutia Tour dan Akbar Wisata Tour)
}

EJI SAROJI

eji.saroji@yahoo.co.id

\begin{abstract}
Eji Saroji (043061211071).The effect of applying the accounting system of the quality of financial reports on the CV. Mutia Tour and travel Akbar Tour. Under the guidance of Gatot Wahyu Nugroho, Drs., Ak., M.Ak., CA and Dr. Darmo H. Suwiryo, SE., M.M

In conducting its business, the company in this case can not be separated from the financial statements. The financial statements have an important role in the process of measurement and assessment of corporate performance as well as useful in decision making . Many parties such as management, shareholders, creditors, governments and others with an interest in the financial statements. Financial statements must be prepared in such a way so as to meet the needs of all those who need them.

Based on the findings and observations that occur in the field (initial research), In carrying out its operations, the company has constraints in preparing its financial statements, in this case the company has not made the recording of financial statements and structured and frequent errors in recording, since less berkompetennya sources human resources in the field of accounting. The Company only records in a simple financial reports and accounting systems in the financial statements have not been used properly. The company therefore difficult to make a tax return, and the owner of the enterprise is difficult for decision-making in carrying out operational activities.The study aims to determine the effects of the application of the accounting system of the quality of financial statements. Variables used in this reseach is the accounting system and the quality of financial statements

Responden in this study were employees CV. Mutia Tour and Akbar Wisata Tour. Of the 30 questionnaires obtained can be used in data processing. Using data analysis IBM SPSS version 23. The statistical method used is simple linear regression test and test hypoteses using partial test ( $t$ test) and the coefficient of determonation $\left(R^{2}\right)$.

After analysis found the partial accounting system affect the quality of financial reporting. The coefficient of determination indicates the effect of the accounting system of the quality of the financial statements at $28,2 \%$ while the rest of $71,8 \%$ are affected by other factors not examined.
\end{abstract}

Keyword : Accounting system, The quality of financial statemen 


\section{PENDAhuluan}

Dewasa ini persaingan dalam dunia usaha khususnya dalam bidang pariwisata semakin ketat, terlebih dengan semakin meningkatnya pengaruh kebutuhan dan keinginan konsumen. Hal ini menyebabkan semua perusahaan yang bergerak di bidang jasa pariwisata, berlomba untuk menghasilkan produk barang dan jasa yang dapat memenuhi kebutuhan dan keinginan konsumen, salah satu usaha yang bergerak di bidang jasa adalah jasa travel. Hal ini dikarenakan banyaknya konsumen yang ingin bepergian dengan maksud dan tujuan yang berbeda-beda.

Perkembangan travel sendiri banyak bermunculan dan bervariasi antara satu perusahaan dengan perusahaan travel lainnya. Maraknya perkembangan usaha di bidang jasa transportasi (travel) dilakukan guna memperlancar kegiatan yang dilakukan oleh para konsumen. Bisnis travel sendiri mengalami perkembangan yang sangat pesat karena dalam bidang transportasi mempunyai kesempatan yang luas dan peluang yang cerah untuk berkembang dengan baik. Hal ini disebabkan adanya pertumbuhan jumlah penduduk yang mengalami kenaikkan terus-menerus dari waktu ke waktu seiring pula diharapkan dengan adannya pertambahan jumlah penduduk yang meningkat dapat pula meningkatkan kebutuhan mereka akan transportasi.

Dalam menjalankan usahanya, perusahaan dalam hal ini tidak terlepas dari laporan keuangan. Laporan keuangan mempunyai peranan penting dalam proses pengukuran dan penilaian kinerja perusahaan serta bermanfaat dalam pengambilan keputusan. Banyak pihak seperti manajemen, pemegang saham, kreditur, pemerintah dan lain-lainnya yang berkepentingan dengan laporan keuangan. Laporan keuangan harus disusun sedemikian rupa agar dapat memenuhi kebutuhan dari semua pihak yang membutuhkannya.

Berdasarkan temuan dan pengamatan yang terjadi di lapangan (penelitian awal), Dalam menjalankan kegiatan operasinya, perusahaan mempunyai kendala dalam menyusun laporan keuangannya, dalam hal ini perusahaan belum melakukan pencatatan laporan keuangan yang baik dan terstruktur dan sering terjadi kesalahan pada pencatatan, karena kurang berkompetennya sumber daya manusia dalam bidang akuntansi. Perusahaan hanya mencatat laporan keuangan secara sederhana, dan sistem akuntansi pada laporan keuangan belum digunakan secara baik dan benar sehingga pemilik perusahaan sulit untuk pengambilan keputusan dalam menjalankan aktifitas operasionalnya.

Untuk mendukung tersedianya laporan keuangan yang berkualitas dibutuhkan suatu penerapan sistem akuntansi yang berfungsi agar laporan keuangan yang dibuat bisa menyediakan informasi yang dibutuhkan oleh pengguna laporan keuangan khususnya bagi pemilik perusahaan. Salah satunya dengan menerapkan sistem akuntansi. Penerapan sistem akuntansi akan berpengaruh terhadap kualitas laporan keuangan, sehingga memudahkan perusahaan dalam membayar pajak, dan laporan keuangan akan terstruktur sehingga menghasilkan informasi keuangan yang jelas untuk membantu pemilik perusahaan mengambil keputusan dalam menjalankan usahanya.

Menurut Budi (2007) mahasiswa Universitas Sumatera Utara Berdasarkan fenomena yang terjadi pada PT. Raya Utama Travel perusahaan tersebut merasa bahwa pendapatan yang maksimal sangat diperlukan agar aktivitas perusahaan dapat berjalan terus menerus. Sumber-sumber pendapatan usaha perusahaan diperoleh dari penjualan ticketing, touring, dan rental mobil. Dalam prakteknya, perusahaan tidak merasa kesulitan dalam mengukur dan mengakui pendapatan yang sebenarnya. Akan tetapi pengakuan dan pengukuran pendapatan yang dilaksanakan apakah telah diukur secara andal sesuai dengan standar akuntansi keuangan. Oleh karena itu, perusahaan memandang pemberlakuan 
sistem akuntansi yang tepat terhadap pendapatan sangat diperlukan demi mendapat informasi yang tepat. Dalam kegiatannya perusahaan haruslah menerapkan sistem keuangan yang baik sehingga dapat mengetahui aktivitas keuangan yang dilakukannya, salah satunya dengan menerapakan sistem akuntansi pada pencatatan laporan keuangannya. Permasalahan tentang pengelolaan aktivitas keuangan merupakan faktor kunci yang dapat menyebabkan keberhasilan, atau justru kejanggalan.

Peneliti berpendapat bahwa dalam menjalankan aktivitas operasionalnya perusahaan harus membuat laporan keuangannya secara jelas, terstruktur dan berkualitas. Karena laporan keuangan yang berkualitas akan memberikan informasi keuangan, terutama bagi pemilik perusahaan untuk bahan evaluasi dan pengambilan keputusan.

Berdasarkan latar belakang tersebut, maka penulis tertarik untuk melakukan penelitian yang berjudul "Pengaruh Penerapan Sistem Akuntansi Terhadap Kualitas Laporan keuangan (studi kasus pada CV. Mutia Tour dan Akbar wisata Tour )

\section{KERANGKA TEORITIS}

\subsection{Sistem}

Untuk memenuhi kebutuhan informasi bagi pihak luar maupun pihak dalam, disusunlah suatu sistem akuntansi, sistem ini direncakan untuk menghasilkan informasi yang berguna bagi pihak dalam maupun luar.

Susanto (2013:22), "sistem adalah kumpulan atau grup dari subsistem atau bagian apapun baik fisik atau nonfisik yang saling berhubungan satu sama lain dan bekerja sama secara harmonis untuk mencapai tujuan tertentu".

V. Wiratna Sujarweni (2015:1), “sistem adalah kumpulan elemen yang saling berkaitan dan bekerja sama dalam melakukan kegiatan untuk mencapai suatu tujuan".

Dari pendapat di atas dapat dismpulkan bahwa sistem merupakan suatu kegiatankegiatan yang saling berhubungan, dimana setiap kegiatan tersebut memliliki bagian yang saling keterkaitan satu sama lain, sehingga dapat mencapai tujuan yang diinginkan dari kegiatan tersebut.

\section{Akuntansi}

Epi Indriani (2013:5), definisi akuntansi dapat ditinjau dari dua sudut pandang, yaitu dari sudut pandang pengguna akuntansi dan proses kegiatan akuntansi. Definisi akuntansi dari sudut pandang pengguna akuntansi, yaitu suatu disiplin ilmu dan atau aktivitas jasa yang menyediakan informasi yang diperlukan untuk melaksanakan kegiatan secara efisien dan mengevaluasi kegiatan suatu entitas atau transaksi yang bersifat keuangan (financial). Adapun dari sudut pandang proses kegiatannya, akuntansi adalah proses pencatatan, penggolongan, peringkasan, pelaporan dan penganalisaan data keuangan suatu entitas. Dari dua definisi tersebut dapat disimpulkan, bahwa secara umum akuntansi adalah suatu sistem informasi keuangan yang menghasilkan laporan kepada pihak-pihak yang berkepentingan mengenai aktivitas ekonomi dan kondisi perusahaan

V. Wiratna Sujarweni (2015:3), akuntansi adalah proses dari transaksi yang dibuktikan dengan faktur, lalu dari transaksi dibuat jurnal, buku besar, neraca lajur, kemudian akan menghasilkan informasi dalam bentuk laporan keuangan yang digunakan pihak-pihak tertentu.

Suwardjono (2011:10), akuntansi di definisikan sebagai seperangkat pengetahuan yang mempelajari perekayasaan penyediaan jasa berupa informasi keuangan kuantitatif unit-unit organisasi dalam suatu lingkungan negara tertentu dan cara penyampaian (pelaporan) informasi tersebut kepada pihak yang berkepentingan untuk dijadikan dasar dalam pengambilan keputusan ekonomi.

Dalam arti sempit sebagai proses, fungsi, atau praktik, akuntansi dapat didefinisikan sebagai berikut:Proses pengidentifikasian, 
pengesahan, pengukuran, pangakuan, pengklasifikasian, penggabungan, peringkasan, dan penyajian data keuangan dasar yang terjadi dari kejadian-kejadian, transaksi-transaksi atau kegiatan operasi suatu unit organisasi dengan cara tertentu untuk menghasilkan informasi yang relevan bagi pihak yang berkepentingan.

Dari pengertian diatas dapat disimpulkan bahwa akuntansi merupakan proses pengidentifikasian, pencatatan, penggolongan, pengikhtisaran dan pelaporan informasi keuangan yang ditujukan untuk menghasilkan informasi yang berguna bagi pihak yang berkepentingan baik intern maupun ektern dalam rangka pengambilan keputusan.

\section{Sistem Akuntansi}

Sistem akuntansi berasal dari dua kata yaitu sistem dan akuntansi. Sistem merupakan jaringan-jaringan yang saling berhubungan satu dengan yang lainnya yang membentuk satu kesatuan.

V.Wiratna Sujarweni (2015:3), adalah kumpulan elemen yaitu formulir, jurnal, buku besar, buku pembantu, dan laporan keuangan yang akan digunakan oleh manajemen untuk mencapai tujuan perusahaan. Sistem akuntansi terdiri dari input yang berupa transaksi yang dicatatkan dalam formulir (input) kemudian diproses (dengan menjurnal, membuat buku besar, membuat buku pembantu) dan hasil akhirnya (output) berupa laporan keuangan yang digunakan manajemen untuk mencapai tujuan perusahaan.

Warren (2015:228), sistem akuntansi adalah metode dan prosedur untuk mengumpulkan, mengelompokan, merangkum, serta melaporkan informasi keuangan dan operasi perusahaan.

Sistem akuntansi berubah melalui proses tiga tahap seiring dengan perkembangan dan perubahan perusahaan. Tiga tahap tersebut adalah :

1. Menganalisis kebutuhan pihak-pihak yang menggunakan informasi.

2. Sistem dirancang untuk dapat memenuhi kebutuhan penggunanya.

3. Sistem ini kemudian diterapkan dan digunakan.
Rancangan sistem akuntansi terdiri atas :

1. Pengendalian internal, adalah kebijakan dan prosedur yang melindungi aset dari penyalahgunaan, memastikan keakuratan informasi bisnis, serta memastikan hukum dan peraturan yang berlaku telah diikuti.

2. Metode pengolahan informasi, merupakan alat yang digunakan sistem untuk mengumpulkan, merangkum, dan melaporkan informasi akuntansi.

Dari beberapa definisi diatas dapat disimpulkan bahwa sistem akuntansi merupakan seperangkat prosedur yang terdiri dari elemen-elemen yang di proses menjadi sebuah informasi keuangan yang akan digunakan oleh pihak yang berkepentingan untuk sebuah pengambilan keputusan

\section{Laporan Keuangan}

Irham fahmi (2013:2), Laporan keuangan merupakan suatu informasi yang menggambarkan kondisi keuangan suatu perusahaan, dan lebih jauh informasi tersebut dapat dijadikan sebagai gambaran kinerja keuangan perusahaan tersebut.

Sadeli (2011:18), laporan keuangan adalah laporan tertulis yang memberikan informasi kuantitatif tentang posisi keuangan dan perubahan-perubahannya, serta hasil yang dicapai selama priode tertentu. Posisi keuangan memberikan gambaran tentang bagaimana susunan kekayaan yang dimiliki perusahaan dan sumber-sumber kekayaan itu didapat. Perubahan posisi keuangan menunjukan kemajuan perusahaan, memberikan gambaran tentang apakah perusahaan memperoleh laba dalam melaksanakan kegiatannya, dan apakah perusahaan mengalami perkembangan yang menunjukan manajemen telah mengelola perusahaan dengan berhasil.

Werner R.Murhadi (2013:1), laporan keuangan merupakan bahasa bisnis. didalam laporan keuangan berisi informasi menegenai kondisi keuangan perusahaan kepada pihak pengguna. Dengan memahami laporan keuangan suatu perusahaan, maka 
berbagai pihak yang berkepentingan dapat melihat kondisi kesehatan keuangan suatu perusahaan.

SAK ETAP (2013:18), laporan keuangan merupakan hasil dari proses akuntansi sebagai penyedia informasi posisi keuangan, kinerja keuangan dan dan laporan arus kas suatu entitas yang bermanfaat bagi sejumlah besar pengguna dalam pengambilan keputusan ekonomi oleh siapapun yang tidak dalam posisi dapat meminta laporan keuangan khusus untuk memenuhi kebutuhan informasi tertentu, dalam memenuhi tujuannya, laporan keuangan juga menunjukan apa yang telah dilakukan manajemen atau pertanggung jawaban manajemen atas sumber daya yang dipercayakan kepadanya.

Dari beberapa definisi diatas dapat disimpulkan bahwa laporan keuangan adalah sebuah catatan informasi keuangan suatu perusahaan yang bertujuan untuk pengambilan keputusan.

\section{Perumusan Hipotesis}

$\mathrm{Ha}=$ Penerapan Sistem Akuntansi berpengaruh terhadap kualitas laporan keuangan.

$\mathrm{H} 0=$ Penerapan Sistem Akuntansi tidak berpengaruh terhadap kualitas laporan keuangan.

\section{III.METODOLOGI PENELITIAN}

\section{Variabel Penelitian}

Berdasarkan judul penelitian yang diambil, yaitu Pengaruh Penerapan Sistem Akuntansi Terhadap Kualitas Laporan Keuangan, maka variabel-variabel yang menjadi penelitian adalah Sistem akuntansi (X) sebagai variabel bebas/ Variable Independent dan Kualitas Laporan Keuangan (Y) sebagai variabel terikat/ Variabel dependent.

\section{Populasi dan Sampel}

Yang menjadi populasi dalam penelitian ini adalah seluruh pegawai yang bekerja di CV. Mutia Tour dan akbar wisata Tour. Teknik sampling yang digunakan dalam penelitian ini adalah dengan teknik non probability sampling dengan menggunakan sampling jenuh. Sampling jenuh adalah teknik penentuan sampel bila semua anggota populasi digunakan sebagai sampel.

\section{Teknik Pengumpulan Data}

Teknik pengumpulan data yang digunakan adalah teknik primer dengan metode observasi, kuisioner atau angket dan wawancara.

\section{Teknik Analisis data}

Teknik analisis data yang digunakan adalah analisis regresi linier sederhana, dengan uji t dan koefisien determinasi.

\section{IV.HASIL PENELITIAN DAN PEMBAHASAN}

\section{Hasil Uji Validitas}

Sugiyono (2012:172) instrumen yang valid berarti alat ukur yang digunakan untuk mendapatkan data (mengukur) itu valid. Valid berarti instrumen tersebut dapat digunakan untuk mengukur apa yang seharusnya diukur. Adapun standar keputusan terhadap butir-butir item yang ada bahwa dalam pengambilam keputusannya dikatakan valid apabila $\mathrm{r}$ hitung lebih besar dari 0,361 maka instrumen tersebut dapat dikatakan valid dan dapat digunakan sebagai alat pengambilan data dalam penelitian.

Tabel 4.1

Hasil Uji Validitas Sistem Akuntansi (Variabel

\begin{tabular}{|c|c|c|c|}
\hline $\begin{array}{c}\text { No } \\
\text { Item }\end{array}$ & $\begin{array}{c}\mathrm{r} \\
\text { hitung }\end{array}$ & $\begin{array}{c}\mathrm{r} \\
\text { tabel }\end{array}$ & Keterangan \\
\hline 1 & 0,634 & 0,361 & Valid \\
\hline 2 & 0,404 & 0,361 & Valid \\
\hline 3 & 0,692 & 0,361 & Valid \\
\hline 4 & 0,367 & 0,361 & Valid \\
\hline 5 & 0,484 & 0,361 & Valid \\
\hline 6 & 0,680 & 0,361 & Valid \\
\hline 7 & 0,708 & 0,361 & Valid \\
\hline 8 & 0,547 & 0,361 & Valid \\
\hline 9 & 0,548 & 0,361 & Valid \\
\hline 10 & 0,680 & 0,361 & Valid \\
\hline
\end{tabular}

Tabel 4.2 
Hasil Uji Validitas Kualitas Laporan

Keuangan (Variabel Y)

Hasil Uji Reliabilitas

Reliabilitas menunjukan keterandalan.

Reliabel dapat dipercaya jadi dapat diandalkan. Suatu data dikatakan reliabel jika nilai Cronbach Alfa diatas 0,6.

\begin{tabular}{|l|l|l|}
\hline Variabel & $\begin{array}{l}\text { Cronbach } \\
\text { Alfa }\end{array}$ & Keterangan \\
\hline $\begin{array}{l}\text { Sistem } \\
\text { Akuntansi }\end{array}$ & 0,774 & Reliabel \\
\hline $\begin{array}{l}\text { Kualitas } \\
\text { laporan } \\
\text { keuangan }\end{array}$ & 0,885 & Reliabel \\
\hline
\end{tabular}

Analisis Regresi Linier Sedehana

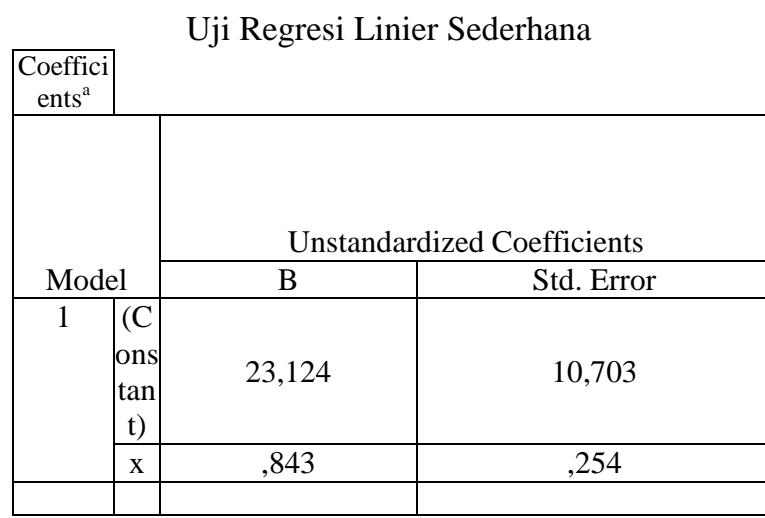

\begin{tabular}{|c|c|c|c|}
\hline No Item & r hitung & r tabel & $\begin{array}{c}\text { Keterang } \\
\text { an }\end{array}$ \\
\hline & & & \\
\hline 1 & 0,683 & 0,361 & Valid \\
\hline 2 & 0,720 & 0,361 & Valid \\
\hline 3 & 0,852 & 0,361 & Valid \\
\hline 4 & 0,683 & 0,361 & Valid \\
\hline 5 & 0,674 & 0,361 & Valid \\
\hline 6 & 0,773 & 0,361 & Valid \\
\hline 7 & 0,491 & 0,361 & Valid \\
\hline 8 & 0,392 & 0,361 & Valid \\
\hline 9 & 0,722 & 0,361 & Valid \\
\hline 10 & 0,481 & 0,361 & Valid \\
\hline 11 & 0,561 & 0,361 & Valid \\
\hline 12 & 0,614 & 0,361 & Valid \\
\hline 13 & 0,773 & 0,361 & Valid \\
\hline 14 & 0,620 & 0,361 & Valid \\
\hline
\end{tabular}

Sumber : data yang telah diolah menggunakan aplikasi IBM SPSS 23 for akuntansi dapat dilihat pada kolom Unstadardized Coefficients bagian B, maka

a Dependent Variable: y

\section{Windows}

Berdasarkan hasil pengolahan data untuk variabel sistem

variabel Sistem akuntansi maka nilai variabel Kualitas laporan keuangan akan naik sebesar 23,124. Sedangkan koefisien regresi untuk varibel pengendalian internal sebesar 0,843. Hal ini menunjukan bahwa setiap ada peningkatan Sistem akuntansi pada CV.Mutia Tour dan Akbar Wisata Tour, maka akan menaikkan tingkat Kualitas Ujin dilakukan untuk menguji pengaruh dari variabel independen terhadap variabel dependen secara individu. Kriteria pengujian hipotesis uji ini dilakukan dengan taraf nyata $\alpha=5 \%(0,05)$ dan derajat pas $(\mathrm{df}=\mathrm{n}-3)$. diperoleh model regresi linier sederhana sebagai berikut :

$\mathrm{Y}=23,124+0,843 \mathrm{X}$

Pada persamaan regresi $\mathrm{X}$ terhadap $\mathrm{Y}$ dapat dijelaskan bahwa jika ada laporan keuangan 0,843. Artinya terjadi pengaruh penerapan Sistem Akuntansi dengan Kualitas laporan keuangan CV.Mutia Tour dan Akbar wisata Tour.

\section{Uji Hipotesis \\ Hasil Uji Parsial (Uji t)}

Adapun kriteria penerimaan dari penolakan hipotesis dilakukan dengan cara membandingkan hasil perhitungan uji-t $\left(t_{\text {hitung }}\right)$ dengan $t_{\text {tabel }}$ dengan keputusan yang dapat diambil ada. 
Uji Parsial (Uji t)

Coefficients $^{\mathrm{a}}$

\begin{tabular}{|c|c|c|c|c|c|c|}
\hline \multirow{2}{*}{\multicolumn{2}{|c|}{ Model }} & \multicolumn{2}{|c|}{ Unstandardized Coefficients } & $\begin{array}{l}\text { Standardized } \\
\text { Coefficients }\end{array}$ & \multirow[b]{2}{*}{$\mathrm{T}$} & \multirow[b]{2}{*}{ Sig. } \\
\hline & & $\mathrm{B}$ & Std. Error & Beta & & \\
\hline 1 & (Constant) & 23,124 & 10,703 & & 2,160 & ,039 \\
\hline & $\mathrm{x}$ & ,843 & ,254 & ,531 & 3,313 & ,003 \\
\hline
\end{tabular}

a. Dependent Variable: $y$

Sumber : data yang telah diolah menggunakan aplikasi IBM SPSS 23 for Windows

Dari tabel 4.11 hasil uji $\mathrm{t}$ yang dilakukan dapat dilihat $t_{\text {hitung }}$ untuk Sistem Akuntansi adalah sebesar 3.313, sedangkan $\mathrm{t}_{\text {tabel }}$ adalah sebesar 2.042 (dengan menggunakan rumus taraf nyata $\alpha=5 \%$

terlihat hasil statistik $t_{\text {hitung }}$ pada tingkat siginifikan 5\% dari nilai sig. $=0,003$ $<$ siginifikansi $0,05 \quad(5 \%)$ yang berarti terdapat pengaruh yang siginfikan antara Sistem Akuntansi terhadap Kualitas laporan keuangan.

\section{Hasil Uji Koefisien Determinasi}

Koefisien determinasi $\left(\mathrm{R}^{2}\right)$ digunakan untuk mengukur seberapa jauh kemampuan model regresi dalam menjelaskan variabel dependen (Y). Koefisien determinasi adalah antara 0 (nol) dan 1 (satu). Nilai koefisien determinasi
$(0,05)$ da derajat pas yaitu $\mathrm{df}=\mathrm{n}-2)$ yaitu $t_{\text {tabel }}(0,05 ; 28)$. Sesuai dengan kriteria pengujian bahwa jika $-t_{\text {hitung }}>-t_{\text {tabel }}(3.313>$ 2.042) maka hipotesis Ho ditolak. Untuk melihat siginifikasinya, yang kecil berarti kemampuan variabel variabel independent dalam menjelaskan variabel - variabel dependen sangat terbatas. Nilai yang mendekati satu berarti variabel independen memberikan hampir semua informasi yang dibutuhkan untuk memprediksi variasi variabel dependen.

Dari tabel Model Summary berikut dapat diketahui nilai $\mathrm{R}^{2}$ ( $R$ Square) pengaruh vartiabel independen yaitu Sistem Akuntansi (X) terhadap Kualitas Laporan keuangan (Y).

Tabel 4.12

Koefisien Determinasi

Model Summary ${ }^{\mathrm{b}}$

\begin{tabular}{|l|r|r|r|r|}
\hline Model & $\mathrm{R}$ & R Square & \multicolumn{1}{c|}{$\begin{array}{c}\text { Adjusted R } \\
\text { Square }\end{array}$} & $\begin{array}{c}\text { Std. Error of the } \\
\text { Estimate }\end{array}$ \\
\hline 1 &, $531^{\mathrm{a}}$ &, 282 &, 256 & 5,940 \\
\hline
\end{tabular}

a. Predictors: (Constant), $x$

b. Dependent Variable: $y$

Sumber : data yang telah diolah menggunakan aplikasi IBM SPSS 23 for Windows dipengaruhi oleh faktor lain yang tidak diteliti

Dari tabel 4.12 diketahui nilai $\mathrm{R}^{2}(R$ Square) untuk CV. Mutia Tour dan Akbar Wisata Tour adalah 0,282, artinya sumbangan pengaruh dari variabel independen yaitu Sistem Akuntansi hanya $28,2 \%$ sedangkan sisanya sebesar $71,8 \%$

\section{Pembahasan Hasil Penelitian}

Berdasarkan hasil penelitian dan pengujian secara statistik yang telah dipaparkan sebelumnya menunjukan variabel Sistem Akuntansi (X) berpengaruh 
positif terhadap kualitas laporan keuangan (Y).

Untuk pengujian pertama dari pengaruh sistem akuntansi terhadap kualitas laporan keuangan bisa dibuktikan dengan uji t yang dilakukan oleh peneliti dimana hasil dari pengaruh sistem akuntansi terhadap kualitas laporan keuangan mendapatkan hasil $t$ hitung > t tabel $(3.313>2.042)$ maka hipotesis Ho ditolak dan Ha diterima. Untuk melihat siginifikasinya, terlihat hasil statistik $\mathrm{t}_{\text {hitung }}$ pada tingkat siginifikan $5 \%$ dari nilai sig. $=0,000<$ siginifikansi $0,05(5 \%)$ yang berarti terdapat pengaruh yang siginfikan antara sistem akuntansi terhadap kualitas laporan keuangan. Jadi dapat disimpulkan bahwa dari hasil pengolahan data yang telah dilakukan bahwa sistem akuntansi berpengaruh terhadap kualitas laporan keuangan yaitu sebesar 28,2\% sedangkan sisanya sebesar $71,8 \%$ dipengaruhi oleh faktor lain yang tidak diteliti.

\section{SIMPULAN DAN SARAN}

\section{Simpulan}

1. Berdasarkan perhitungan SPSS menyatakan bahwa standar deviasi

4. keuangan, agar tujuan perusahaan tercapai dan operasional perusahaan berjalan secara efektif dan efisien

\section{DAFTAR PUSTAKA}

\section{BUKU}

Assauri.2013.Manajemen Pemasaran. Jakarta : RajaGrafindo (Rajawali Press)

Belkoui, Ahmed-Riahi. 2011. Teori Akuntansi. Jakarta Selatan: Salemba Empat

Fahmi, Irham.2013. Analisis Laporan Keuangan. Bandung: Alfabeta

Ikatan Akuntan Indonesia.2015. Standar Akuntansi Keuangan

Indriani, Epi. 2013. Akuntansi Gampang Untuk Pemula dan Orang Awam, Jakarta: Dunia Cerdas lebih kecil dari nilai rata-rata, yang berarti penerapannya cukup baik.

2. Berdasarkan perhitungan SPSS menyatakan bahwa standar deviasi lebih kecil dari nilai rata-rata, yang berarti kualitas laporan keuangan cukup baik.

3. Penerapan Sistem akuntansi (X) berpengaruh positif terhadap Kualitas Laporan Keuangan, artinya semakin baik penerapan Sistem Akuntansi yang dijalankan maka semakin baik pula Kualitas laporan keuangan (Y) pada perusahaan jasa travel

\section{Saran}

1. Perusahaan perlu meningkatkan pengetahuan tentang pencatatan keuangan khususnya sistem akuntansi, karena sistem akuntansi sangat besar perannya bagi kinerja perusahaan.Sumber Daya Manusia lebih memahami lagi tentang laporan keuangan yang sesuai dengan PSAK.

2. Perlu adanya Sumber Daya Manusia yang berkompeten dalam membuat dan menyusun laporan keuangan, sehingga menghasilkan laporan keuangan yang berkualitas.

3. Perusahaan harus memperhatikan sistem akuntansi dan laporan Lupiyoadi, Rambat dan Ikhsan B Ridho. 2015. Praktikum Metode Riset Bisnis, Jakarta: Salemba Empat

Marwoto, Bambang Heru dan Susatyo Herlambang. 2014. Pengantar Ilmu Bisnis, Jogjakarta: Parama Publishing

Murhadi, Werner.2013. Analisis Laporan Keuangan Proyeksi dan Valuasi Saham,Jakarta : Salemba Empat

Nayla Akifa P. 2013. Cara Praktis Menyusun Laporan Keuangan, Jogjakarta: Laksana

PSAK. 2015

Sadeli, L. 2011. Dasar-Dasar Akuntansi, cetakan ke-7, Jakarta : PT. Elex Media Komputindo Kelompok Gramedia

SAK-ETAP. 2013 
Sugiyono. 2012. Metode Penelitian Bisnis, Bandung : Alfabeta

Sugiyono. 2014. Metode Penelitian Bisnis, Bandung : Alfabeta

Sujarweni V. Wiratna. 2015. Sistem Akuntansi. Jogjakarta: Pustaka Baru Press

Sunyoto, Danang. 2013. Metode Penelitian Akuntansi, Bandung: Refika Aditama

Susanto, A.2013. Sistem Informasi Akuntansi, cetakan pertama, Bandung : Lingar Jaya

Suwardjono. 2011. Teori Akuntansi Perekayasaan Pelaporan Keuangan, cetakan ke 4, Yogyakarta : BPFE-YOGYAKARTA

Warren et al..,. 2015. Pengantar Akuntansi,cetakan ke-25, Jakarta : Salemba Empat

\section{JURNAL PENELITIAN}

Mulia,Budi.2007. Pengakuan dan pengukuran pendapatan menurut PSAK No.23 pada PT Raya Utama travel medan. Usulan penelitian pada Universitas Sumatera Utara

Permadi,Angga Dewi. 2013.Pengaruh Penerapan Sistem Akuntansi Keuangan Pemerintah Daerah Terhadap Kualitas Laporan Keuangan Daerah. Usulan Penelitian pada Universitas Widyatama

Maulana Yusron Taufik . 2015. Penerapan Akuntansi Berdasarkan SAK E-TAP Pada Usaha Kecil Menengah. Usulan Penelitian pada Universitas Muhammad 
